\title{
Covered Stent Embolization: a case of acute coronary intervention with a series of multiple complications
}

\author{
Firas R. AL-Obaidi' ${ }^{1,2}$, Mohammed H. AL-Ali ${ }^{3,4}$, Tahsin AL-Kinani ${ }^{3,4}$, Mohammed AL-Myahi ${ }^{4}$ \\ ${ }^{1}$ AL-Zahra College of Medicine/ University of Basrah, Iraq \\ ${ }^{2}$ Basrah Cardiac Centre, Iraq \\ ${ }^{3}$ College of Medicine/ University of Thi Qar, Iraq \\ ${ }^{4}$ Nassiriyah Heart Centre, Iraq \\ *The institution at which work was done is Nassiriyah Heart Centre, Iraq
}

\begin{abstract}
Complications during acute coronary intervention are rare and life-threatening. We present a case of a patient with acute coronary syndrome admitted for percutaneous coronary intervention to the left anterior descending artery. The straightforward procedure was challenged by multiple complications of coronary artery perforation, cardiac tamponade, stent loss, and ventricular fibrillation. The management was complicated by covered stent embolization into the left circumflex artery without a wire inside. We were able to retrieve the lost covered stent by re-accessing the lumen with a coronary guidewire followed by advancing a balloon distal to the stent and extraction of the whole system outside. The case illustrates the possibility of facing multiple complications in one procedure including the loss of covered stent and how to prevent and manage this serious complication.
\end{abstract}

Key words: acute coronary syndrome, $\mathrm{PCl}$ complications, covered stent, stent loss, stent retrieval, coronary perforation.

\section{Embolizace krytého stentu: případ akutní koronární intervence provázené řadou komplikací}

Komplikace během akutní koronární intervence jsou vzácné, ale mohou být život ohrožující. Uvádíme př́pad pacienta s akutním koronárním syndromem, který byl přijat k perkutánní koronární intervenci ramus interventricularis anterior. Během tohoto jinak rutinního zákroku jsme čelili řadě problémů v podobě perforace koronární arterie, srdeční tamponády, ztráty stentu a komorové fibrilace. Výkon zkomplikovala embolizace krytého stentu do ramus circumflexus bez zavedeného vodicího drátu v této koronární tepně. Ztracený krytý stent jsme dokázali retrahovat zavedením koronárního vodiče do lumen koronární tepny s posunutím balonku distálně od stentu a následným vyjmutím celého systému. Tento případ dokládá možnost výskytu mnohočetných komplikací v rámci jednoho výkonu, včetně ztráty krytého stentu, a ukazuje způsob, jak této závažné komplikaci předcházet a jak ji řešit.

Klíčová slova: akutní koronární syndrom, komplikace PCl, krytý stent, ztráta stentu, extrakce stentu, koronární perforace.

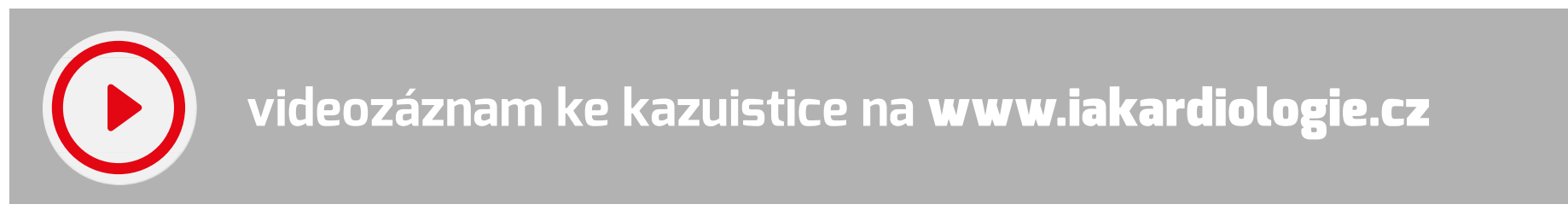
Abbreviations
DES - drug-eluting stent
LCX - left circumflex artery
CABG - coronary artery bypass grafting
$L A D$ - left anterior descending artery
$\mathrm{Ml}$ - myocardial infarction 
$\mathrm{PCl}$ - percutaneous coronary intervention VF - ventricular fibrillation

\section{Learning objectives}

Complications during coronary artery interventions may arise even in a technically easy procedure. Knowledge and experience of the management options for the different types of iatrogenic complications are essential to avoid morbidity and mortality of treated patients. Loss of a covered stent can occur, and adherence to a proper deployment technique is the essential step to prevent this devastating complication.

\section{Introduction}

In the contemporary practice of coronary intervention with advances in the technology, the incidence of major complications is low. However, multiple complications in one session can occur despite the odds of rarity which may turn a straightforward procedure into a nightmare. Major periprocedural complications are acute vessel closure, coronary artery perforation, and device embolization including stent loss (1).

In this case, we illustrate the possibility of facing multiple complications in one procedure including the very rare covered stent loss.

\section{Case presentation}

A 64-year-old male smoker patient with no significant past medical history presented with severe chest pain lasting for a few hours. In the emergency room, the patient was haemodynamically stable with no abnormalities on cardiac examination. An electrocardiogram showed a sinus rhythm with biphasic T waves in the anterior leads (V2-4). Laboratory tests indicated elevated troponin titre. Within one hour, the patient was referred to our tertiary centre for urgent coronary intervention. He received a loading dose of ticagrelor (180 mg) and was then admitted directly to the cardiac catheterization laboratory.

The coronary angiogram, through right femoral artery access using 7-F sheath and Judkins Left $3.5 \times 6$ F guiding catheter, showed a mid-LAD critical lesion (Figure 1, Video 1) without significant disease in other vessels. A decision was made to proceed to $P C I$ to the LAD. The left coronary system was engaged using Judkins Left 3.5, 6F guide catheter and unfractionated heparin (7,500 units) was given intravenously.
A hydrophilic floppy guidewire 0.014 crossed the lesion easily into the distal LAD and the lesion was predilated with a balloon $2.0 \times 10 \mathrm{~mm}$ inflated up to 16 bar followed by deployment of a drug-eluting stent (Promus Element) $2.75 \times$ $24 \mathrm{~mm}$ inflated up to 14 bar.

At that time, the patient was haemodynamicaIly stable with no significant dyspnoea, but we noted staining distal to the stent indicating coronary perforation (Figure 2, Video 2). Echocardiography showed mild pericardial effusion. A balloon $2.0 \times$ $20 \mathrm{~mm}$ was introduced, and multiple inflations were attempted in short time segments without benefit as severe chest pain developed with every inflation. The patient started to deteriorate with severe dyspnoea, chest pain, and shock as the perforation propagated to grade III (Video 3). The surgical team was alarmed and helped with pericardiocentesis through subxiphoid access under fluoroscopy guidance, aspirating about 200 cc of haemorrhagic pericardial fluid after which the haemodynamic status restored, but the patient was still irritable with dyspnoea. At the same time, we attempted sealing of the perforation using the GRAFTMASTER ${ }^{\circledR}$ RX coronary stent graft system (GM; Abbott Vascular, Santa Clara, CA, USA) $2.8 \times$ $19 \mathrm{~mm}$ distal to the DES that inflated subnominally (14 bar) due to concerns about oversizing (Figure 3, Video 4). However, the patient was restless and agitated, and unfortunately post-inflation angiography showed that the covered stent had dislodged into the proximal LAD with the deployment balloon out of the stent. Immediately, we advanced the balloon just distal to the stent and inflated it up to 6 bar, and then removed the whole system outside.

While inspecting the system, we could not find the dislodged covered stent. So, we re-engaged the left coronary system to find the lost stent migrated into the proximal LCX. After several attempts, we successfully crossed the covered stent lumen with the hydrophilic floppy RIDER guidewire $0.014 \mathrm{~mm}$ followed by advancing a compliant balloon $2.0 \times 20 \mathrm{~mm}$ outside the distal end of the stent. The balloon was inflated up to 10 bar followed by removing everything (the catheter and the wire with the stent and the balloon) (Figure $4 \mathrm{~A}-\mathrm{E}$, Videos $5 \mathrm{~A}$ and $\mathrm{B}$ ).

At this stage, the patient's blood pressure was borderline $(100 / 50 \mathrm{mmHg})$, and we were able to rapidly advance a new covered stent (GRFATMASTER) $2.8 \times 26 \mathrm{~mm}$ to overlap with the distal end of the DES, and inflated it up to burst
Figure 1. Coronary angiography showing a mid- LAD critical lesion

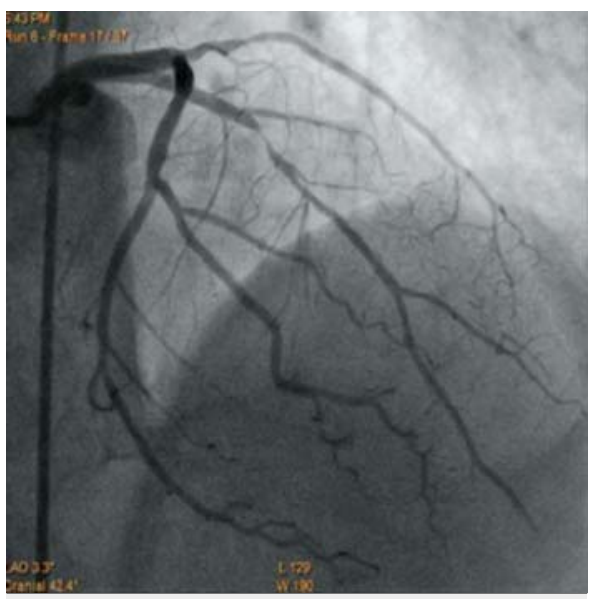

LAD - Left Anterior Descending Artery

Figure 2. Angiographic view post-deployment of the DES in the mid-LAD

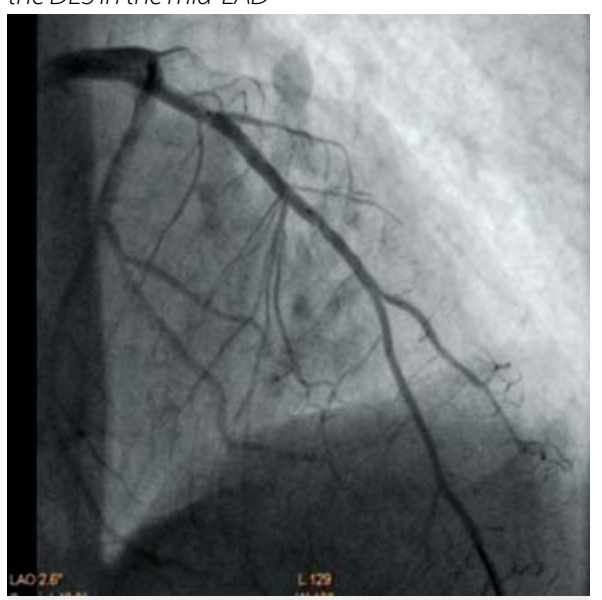

DES-Drug-Eluting Stent

Figure 3. Initial position of the covered stent at the site of perforation before embolization

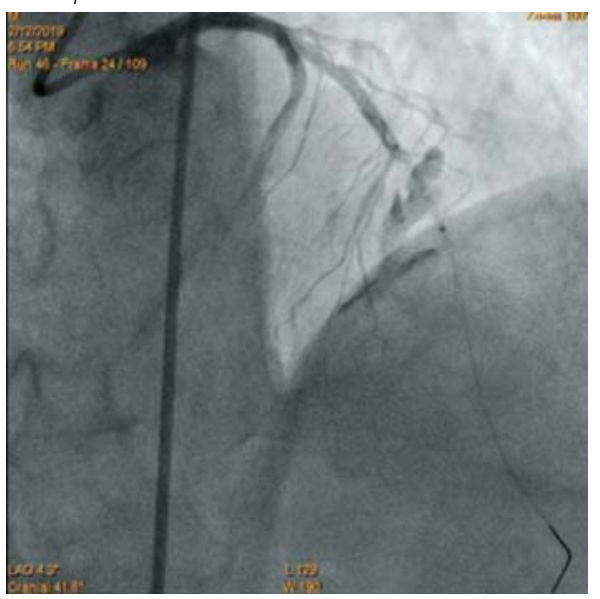

pressure (16 bar) multiple times. Angiographic views showed cessation of the perforation jet with TIMI III flow and no major side-branch loss (Figure 5, Video 6). Protamine was not given during the procedure as we were concerned about the risk of thrombosis of the drug-eluting stent.

The patient's condition stabilized and he was transferred to the coronary care unit. 
Figure 4. A-Covered stentembolized into the LCX artery with no wire inside; B-Successful wire crossing into the lumen of the lost covered stent; $C$ and D-Extraction of the whole system outside; $E$-Extracted covered stent

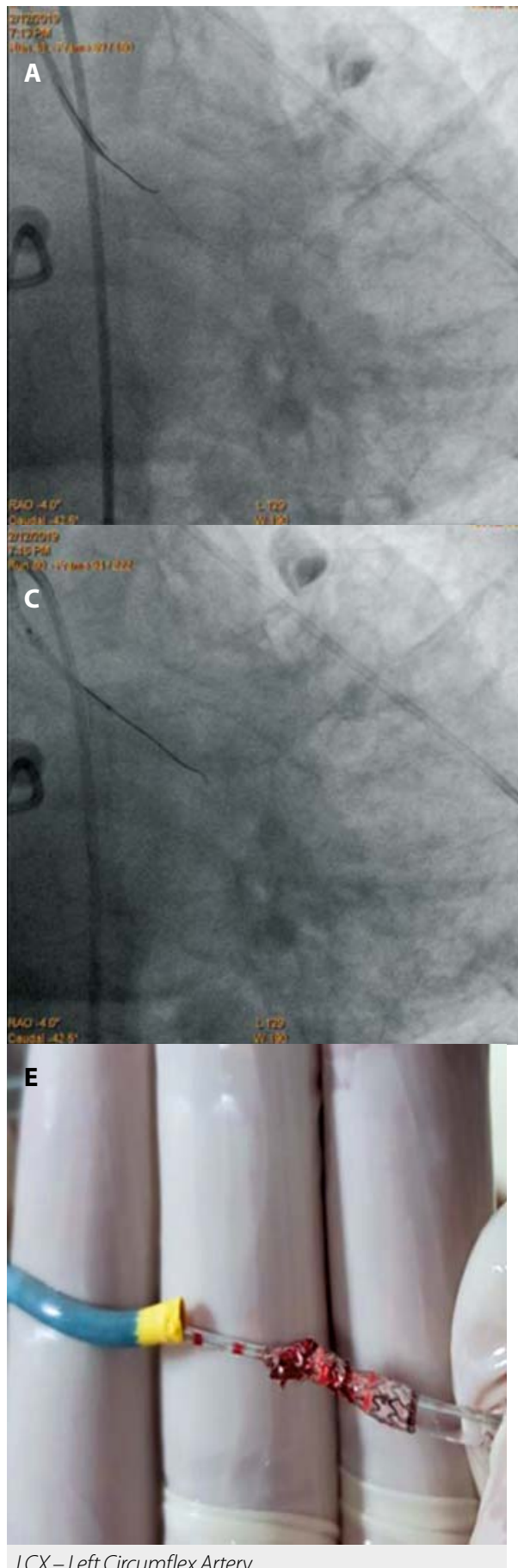

LCX-Left Circumflex Artery

However, ten minutes later, the patient collapsed and developed VF for which he received DC shock and was brought back to the catheterization laboratory where angiography revealed patent stents with TIMI III flow. The pigtail catheter in the pericardium was repositioned and another 150 cc of haemorrhagic fluid aspirated, followed by blood transfusion resulting in stabilization of the patient's condition.

The patient was discharged from the hospital four days later with uneventful recovery and kept on dual antiplatelet therapy (aspirin and ti-

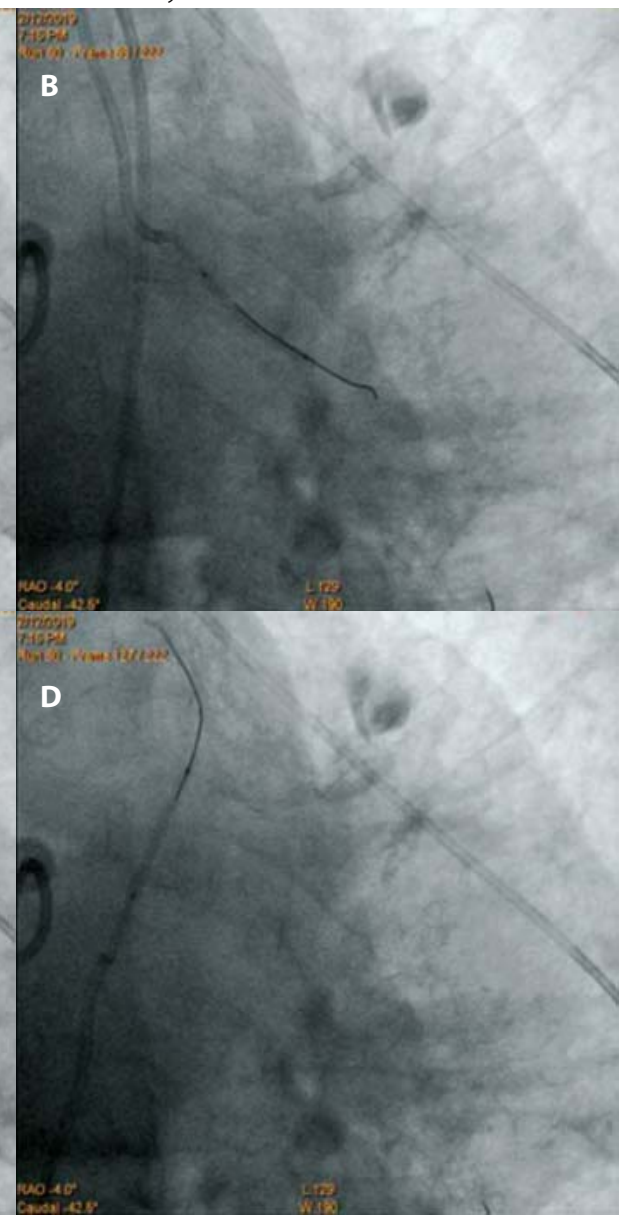

cagrelor) planned to be continued for more than one year. At nine months' follow-up, the patient was free from chest pain with a good functional status and normal LV systolic function.

\section{Discussion}

Periprocedural complications have adverse effects on both short - and long-term prognosis of patients (2). The management of iatrogenic complications is based on expert recommendations derived mainly from case series and registries as randomized trials cannot be conducted taking into consideration the emergency situation and rarity of the events.

Coronary perforation is rare with an incidence ranging from 0.1 to $3 \%$, with a higher rate being reported with interventions for chronic total occlusion. The main causes of coronary perforation are oversized balloon or stent, use of atheroablative devices, and exit of hydrophilic guidewires $(3,4)$. Coronary perforations can cause significant morbidity (periprocedural MI, cardiac tamponade, cardiogenic shock, stroke, and impaired renal function) and mortality (up to $10 \%$ in-hospital death rate) (5). Management strategies vary from prolonged balloon inflation, reversal of heparin, coils, fat embolization, use of covered stents, emergency pericardiocentesis to emergency cardiac surgery (6).

In our case, the perforation was most likely due to guidewire exit which occurred despite smooth passage and resting of wire tip in the distal LAD away from the mid segment where the perforation occurred. The perforation point was far from the lesion site where predilation and stenting had been done. Our theory is that sliding of the hydrophilic wire into small branches during advancement may have caused the perforation. The perforation was managed with multiple balloon inflations and emergency pericardiocentesis, and finally sealed with a covered stent.

Covered stents are used mainly in the management of grade III coronary perforation (46.4\% of cases) (7). There are four types of covered stents: polytetrafluoroethylene (most commonly used), polyurethane, pericardium, and autologous vein-artery stents (8). Adverse events associated with a covered stent are stent thrombosis (11.9\%), target lesion revascularization due to in-stent restenosis (22.4\%), coronary dissection (9.4\%), slow flow / no flow (15.6\%), and side-branch closure (3.1\%) (9). The mortality is high (16.6\%), with the majority occurring in the first month post $\mathrm{PCl}$ (10).

Our case was complicated by another rare, but feared complication of stent loss. In general, stent loss has an incidence rate of $0.32 \%$, with intervention in calcified and tortuous arteries being the main risk factor for stent loss. Stent embolization can result in acute $\mathrm{Ml}$, emergency $\mathrm{CABG}$, bleeding, and even death (11). To the best of our knowledge, no data have been reported on covered stent loss.

Retrieval of a lost stent depends on whether or not the wire is still inside the stent (free stent). If the wire is still inside, retrieval can be done with a balloon or microcatheter. If the stent is free without a wire inside, a snare or extension catheter can be utilized. If retrieval fails, other options include use of another wire for wrapping, forceps, crushing by deploying another stent, and finally surgery (1).

In our case, we first attempted to retrieve the stent by inflating the balloon distal to the stent, which was unsuccessful probably due to slippage of the stent from the wire and the balloon. In the second attempt, the challenge was more difficult as the stent was free without a wire. The trick was to cross the already inflated stent lumen with the wire. This was possible after a few attempts 
VIDEOKAZUISTIKA |

followed by sliding the balloon distally to finish extraction of the whole system. Although the technique is not mentioned in the management of stent loss, it is worth considering in the case

\section{REFERENCES}

1. Giannini F, Candilio L, Mitomo S, Ruparelia N, Chieffo A, Baldetti L, et al. A Practical Approach to the Management of Complications During Percutaneous Coronary Intervention. JACC: Cardiovascular Interventions. 2018; 11(18): 1797-810. 2. Levine GN, Bates ER, Blankenship JC, Bailey SR, Bittl JA, Cercek B, et al. 2011 ACCF/AHA/SCAI Guideline for Percutaneous Coronary Intervention: a report of the American College of Cardiology Foundation/American Heart Association Task Force on Practice Guidelines and the Society for Cardiovascular Angiography and Interventions. Circulation. 2011; 124(23): e574-651.

3. Shimony A, Joseph L, Mottillo S, Eisenberg MJ. Coronary artery perforation during percutaneous coronary intervention: a systematic review and meta-analysis. Canadian Journal of Cardiology. 2011; 27(6): 843-850.

4. Patel VG, Brayton KM, Tamayo A, Mogabgab O, Michael TT, Lo N, et al. Angiographic success and procedural complica- of losing an inflated stent with no wire inside. To prevent this serious complication, high inflation pressure is always recommended to prevent dislodgement and to avoid restenosis in the future.
Conflict of interest: none to declare for Firas $R$ AL-Obaidi, Mohammed H. AL-Ali,

Tahsin AL-Kinani and Mohammed AL-myahi. Funding: no funding for this paper. tions in patients undergoing percutaneous coronary chronic total occlusion interventions: a weighted meta-analysis of 18,061 patients from 65 studies. JACC: Cardiovascular Interventions. 2013; 6(2): 128-136.

5. Shaukat A, Tajti P, Sandoval Y, Stanberry L, Garberich R, Nicholas Burke $M$, et al. Incidence, predictors, management and outcomes of coronary perforations. Catheterization and Cardiovascular Interventions. 2019; 93(1): 48-56.

6. Lemmert ME, van Bommel RJ, Diletti R, Wilschut JM, de Jaegere PP, Zijlstra F, et al. Clinical Characteristics and Management of Coronary Artery Perforations: A Single-Center 11-Year Experience and Practical Overview. J Am Heart Assoc. 2017; 6(9).

7. Al-Lamee R, lelasi A, Latib A, Godino C, Ferraro M, Mussardo $M$, et al. Incidence, predictors, management, immediate and long-term outcomes following grade III coronary perforation. JACC Cardiovascular interventions. 2011; 4(1): 87-95.
8. Ismail Kilic K, Enrico F, Roberta S, Gianluca C, Nicolas F, Sara A-S, et al. Coronary covered stents. Eurolntervention. 2016; 12(10): 1288-1295.

9. Hachinohe D, Latib A, Laricchia A, lannopollo G, Demir OM, Ancona MB, et al. Long-term follow-up of covered stent implantation for various coronary artery diseases. Catheterization and cardiovascular interventions : official journal of the Society for Cardiac Angiography \& Interventions. 2019; 94(4): 571-577.

10. Harnek J, James SK, Lagerqvist B. Very long-term outcome of coronary covered stents: a report from the SCAAR registry. Eurolntervention. 2019; 14(16): 1660-16667.

11. Brilakis ES, Best PJM, Elesber AA, Barsness GW, Lennon RJ, Holmes Jr. DR, et al. Incidence, retrieval methods, and outcomes of stent loss during percutaneous coronary intervention: A large single-center experience. Catheterization and Cardiovascular Interventions. 2005; 66(3): 333-340. 